\title{
強震観測記録に基づく 2016 年熊本地震の広带域震源特性 BROADBAND SOURCE CHARACTERISTICS OF THE 2016 KUMAMOTO EARTHQUAKE ESTIMATED FROM STRONG MOTION RECORDS
}

\author{
佐 藤 智 美*
}

\author{
Toshimi SATOH
}

\begin{abstract}
We estimate the broadband source model of the 2016 Kumamoto earthquake based on the empirical Green's function method by considering fmax estimated in this study and nonlinear amplification factors. The case assuming the southeast dipping fault near Mt. Aso is slightly better to simulate records than the case assuming the northwest dipping fault there. The SMGAs for both cases located at the Aso gap area and extend to the inside of northwestern region of the Aso caldera. The short period spectral level, area of total SMGAs and the stress drop of SMGAs for both cases are average as crustal earthquakes.
\end{abstract}

\section{Keywords : The 2016 Kumamoto earthquake, Empirical Green's function method, Strong motion generation area, Broadband source model, Scaling relation, fmax 2016 年熊本地震, 経験的グリーン関数法, 強震動生成域, 広帯域震源モデル, スケーリング則, fmax}

\section{1. はじめに}

2016 年熊本地震では、 4 月 14 日の $M_{\mathrm{s}} 6.5$ の地震、 4 月 16 日の $M_{\mathrm{J}} 7.3$ の地震(本研究では本震と呼ぶ)で震度 7 となるなど、益城町 を中心とした震源域で大きな被害に見舞われた。強震観測網が整備 された 1995 年兵庫県南部地震 $\left(M_{\mathrm{J}} 7.2\right)$ 以降、 $M_{\mathrm{J}} 7.3$ は 2003 年鳥取 県西部地震と同じで、地殼内地震では最大である。したがって、強 震記録に基づきこの地震の震源特性を検討することは、地殼内地震 の強震動予測の高度化に寄与寸ると考えられる。これまで、多数の 研究者により、周期 1 秒程度以上の観測記録に基づく理論グリーン 関数を用いた波形インバージョン例えば 1) 4)、周期 0.5 秒程度以上の 経験的グリーン関数を用いた波形インバージョン 5),6がなされ、す ベり量等が推定されている。本研究では、経験的グリーン関数法に 基づき、建築物に対する入力地震動策定や安全性評価のために重要 な周期 $0.1 \sim 5$ 秒を対象として、強震動生成域から成る広帯域震源モ デルの推定を行う。そして、推定された短周期レベル、強震動生成 域の総面積のスケーリング則、強震動生成域の応力降下量に関して、 過去の地款内地震との比較を行う。

本震に対して強震動生成域から成る広帯域震源モデルを経験的グ リーン関数法により推定した研究として、地款内地震のスケーリン グ則の適用性の検討を目的とした Irikura et al.7)の研究がある。 Irikura et al. 7)では、2 種類のすべり量分布に基づき、フォワード モデリングにより広帯域震源モデルを推定している。2 種類の広帯 域震源モデルは、強震動生成域が 1 個のモデルと、3 個のモデルで あり、破壊伝播速度は一定である。2 種類の広帯域震源モデルの強 震動生成域の総面積や応力降下量は同レベルであるが、個々の強震 動生成域の位置や大きさは異なっている。また、要素地震と本震の $f_{\max }$ の違いや、地盤の非線形性の影響は考慮されていない。本研究 では、本震および震源域の要素地震を含む中規模地震の $f_{\max }$ を推定 し、これを経験的グリーン関数法で用いる。また、K-NET 観測点 では、中規模地震の弱震動の $\mathrm{H} / \mathrm{V}$ の平均值と本震の強震動の $\mathrm{H} / \mathrm{V}$ を算出し、両者の比により地盤の非線形性の影響を補正する。

また、引間 3)は、波形インバージョンにより推定したすべり速度 時間関数に基づき、布田川断層側の破壊伝播速度が局所的には $3.2 \mathrm{~km} / \mathrm{s}$ 程度とやや速いこと指摘している。一方、Pulido $\left.{ }^{8}\right)$ は、バッ クプロジェクションに基づき、断層破壊の後半部で破壊伝播速度が $\mathrm{S}$ 波速度を超えることを指摘している。本研究では、破壊伝播の性 状を捉えるため、はじめに、本震の上下成分の $\mathrm{P}$ 波初動の記録から、 $\mathrm{STA} / \mathrm{LTA}^{9}{ }^{9}$ により震源での初期破壊と主破壊の時間差を推定し、第 1 強震動生成域の破壊開始点の位置と破壊開始時間を設定する。そし て、他の強震動生成域の破壊開始時間と位置、各強震動生成域の面 積と応力降下量の他、布田川断層側と日奈久断層側の強震動生成域 内の破壊伝播速度を推定する。

地表亀裂調查例えば 10)では、阿蘇のカルデラ内まで亀裂が観測され ているが、震源断層がどこまで続いているかを解明することは、本 震の震源断層長さや断層面積の算出に重要である。Irikura et al. ${ }^{7)}$ の強震動生成域は、阿蘇のカルデラまでは伸びていない。Lin et al. ${ }^{11)}$ は、波形インバージョンと地表亀裂調査に基づき、阿蘇のカル デラの下で破壊が止まったと結論づけている。この Lin et al. ${ }^{11) や ~}$ Asano and Iwata ${ }^{1)}$ 、Kubo et al. ${ }^{2)}$ 、引間 ${ }^{3)}$ 、芝 5)の波形インバージ ヨンや Irikura et al. 7)の広帯域震源モデルでは、北西傾斜の断層を 仮定している。一方、地殸変動に基づく研究 12),13)では、阿蘇付近の 断層面を南東傾斜とした震源モデルが推定されている。Yoshida et

* 清水建設侏技術研究所 上席研究員 - 博士 (工学)

Institute of Technology, Shimizu Corporation, Chief Researcher, Dr.Eng. 
al.4) は、阿蘇付近の断層面を南東傾斜とした波形インバージョンを 行ない、す心゙り量分布は北西傾斜とした場合と大きな違いはないも のの、震源モデルから計算される変位が北西傾斜の場合より地殼変 動と合うことを示している。そこで、本研究では、北西傾斜を仮定 して広帯域震源モデルを推定後、阿蘇付近の断層面のみを南東傾斜 として、グリッドサーチ手法で南東傾斜断層面内の強震動生成域と 破開始点を推定し、断層面の設定による違いと、強震動生成域がど こまで伸びているかについて考察する。

\section{2. fmax の推定}

(1) データと手法

佐藤 14),15) は、スペクトルインバージョンに基づき、1997 年〜2016 年 4 月 19 日までに 2016 年熊本地震周辺で発生した $M_{\mathrm{J}} \geqq 4.0$ 、深さ $20 \mathrm{~km}$ 以下の地震のうち、F-net の $\mathrm{CMT}$ 解の得られている 37 地震 の震源スペクトルを分離し、コーナー周波数、短周期レベルを推定 している。本研究では、その震源スペクトルを用いて $f_{\max }$ を推定す る。Fig.1には、佐藤 14),15)の用いた地震の震央位置(気象庁)、CMT 解と強震観測点の位置を示寸。K-NET、KiK-net 地表、KiK-net 地 中、気象庁 95 型震度計の記録を用いている。

$f_{\max }$ は、地盤増幅特性の影響を除去するため、佐藤 16) と同じ手法 で 2 つの地震の震源スペクトル比を用いて推定する。 $\omega^{-2}$ モデルに $f_{\max }$ を考慮した加速度震源スペクトル $M_{i}(f)$ は、周波数 $f$ の関数とし て(1)式 17)で表す。

$$
M_{i}(f)=\frac{(2 \pi f)^{2} M_{0}}{1+\left(\frac{f}{f_{0}}\right)^{2}} \frac{1}{\sqrt{1+\left(\frac{f}{f_{\max }}\right)^{n}}}
$$

$i$ は、 $i$ 地震を表す指標であり、 $M_{0}$ は F-net の地震モーメント、 $f_{0}$ はスペクトルインバージョンで推定したコーナー周波数である。佐 藤 16)では、全地震に共通の $n$ も推定しているが、 $f_{\max }$ と $n$ にトレー ドオフがあることから、既往の研究 18),199に基づき $n=4$ と設定した。 地震本部 20)では、 $n=4.2^{18)}$ が使われている。基準地震は、観測加速 度震源スペクトルの形状から $f_{\max }$ が最大と考えられる地震を選択寸 る。そして、基準地震の $f_{\max }$ を $5 \mathrm{~Hz}$ から $30 \mathrm{~Hz}$ までの $1 \mathrm{~Hz}$ 刻みと した各グリッドポイントで、次式の残差 $J\left(f_{\max }\right)$ が最小となるように、 他の地震の $f_{\max }$ を改訂準ニュートン法 ${ }^{21}$ により推定する ${ }^{16)}$ 。

$$
J\left(f_{\text {max }}\right)=\sum_{i=2}^{N} \int_{f_{1}}^{f_{2}}\left|\log _{10} \frac{O_{i}(f)}{O_{1}(f)}-\log _{10} \frac{M_{i}(f)}{M_{1}(f)}\right| d f
$$

ここで、 $O_{i}(f)$ は、観測加速度震源スペクトル、 $N$ は地震数 37 であ る。 $\dot{I}=1$ は、基準地震を意味する。 $f_{1}$ は $4 \mathrm{~Hz} 、 f_{2}$ は $20 \mathrm{~Hz}$ である。 $J\left(f_{\max }\right)$ が最小のグリッドポイントの場合が最適值となる。

\section{(2) 推定結果}

Table1には、本震と経験的グリーン関数法で要素地震として用い る 2 つの地震( $\mathrm{EQ} 1 、 \mathrm{EQ} 2$ )、及び $f_{\max }$ 推定の際に基準地震として用 いる地震(Ref. EQ)の諸元と、本研究で推定した $f_{\max }$ を示す。短周期 レベル $A$ は、本震のみ後述の経験的グリーン関数法で推定した值で ある。Fig.2 には、基準地震の $f_{\max }$ と残差 $J\left(f_{\max }\right)$ の関係を示す。こ れに基づき、基準地震の $f_{\max }$ は $9 \mathrm{~Hz}$ と推定されている。Fig.3 には、 本震、 $\mathrm{EQ} 1 、 \mathrm{EQ} 2$ の基準地震 (Ref. EQ)に対する観測加速度震源ス ペクトル比 $O i(f) / O_{1}(f)$ とモデル加速度震源スペクトル比 $M_{i}(f) / M_{1}(f)$

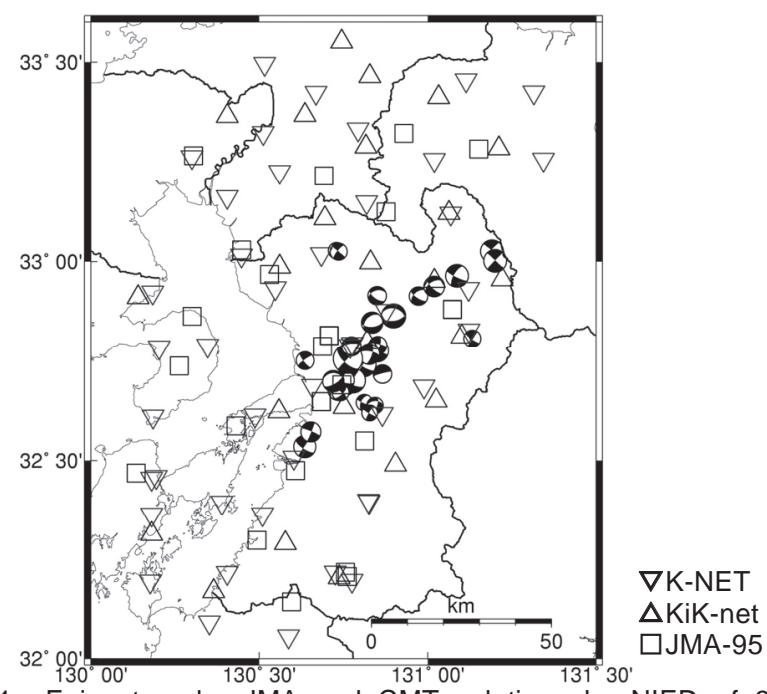

Fig.1 Epicenters by JMA and CMT solutions by NIED of 37 earthquakes with the locations of strong motion stations used for the spectral inversion in Satoh ${ }^{14), 15)}$

Table1 Earthquake list

\begin{tabular}{|l|c|c|c|c|c|c|}
\hline & Date \& Time & $M_{\mathrm{J}}^{*}$ & $\begin{array}{c}\text { Depth } \\
{[\mathrm{km}]}\end{array}$ & $M_{0}^{\dagger}[\mathrm{Nm}]$ & $\begin{array}{c}A \\
{\left[\mathrm{Nm} / \mathrm{s}^{2}\right]}\end{array}$ & $\begin{array}{c}f_{\max }^{\ddagger} \\
{[\mathrm{Hz}]}\end{array}$ \\
\hline Main shock & $2016-04-1601: 25$ & 7.3 & 12.4 & $4.12 \mathrm{E}+19$ & $1.88 \mathrm{E}+19^{\ddagger}$ & 4.4 \\
\hline EQ1 & $2016-04-1422: 38$ & 5.0 & 11.1 & $2.42 \mathrm{E}+16$ & $8.72 \mathrm{E}+17^{\S}$ & 5.8 \\
\hline EQ2 & $2016-04-1423: 43$ & 5.1 & 14.1 & $2.71 \mathrm{E}+16$ & $1.04 \mathrm{E}+18^{\S}$ & 6.4 \\
\hline Ref. EQ & $1997-04-2310: 24$ & 4.1 & 12.5 & $3.34 \mathrm{E}+15$ & $1.70 \mathrm{E}+17^{\S}$ & 9.0 \\
\hline
\end{tabular}

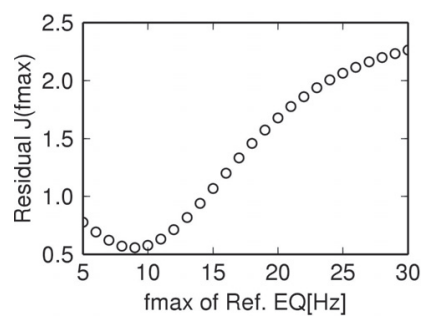

Fig.2 Relation between $f_{\max }$ of R ef.EQ and residual $\mathrm{J}\left(\mathrm{f}_{\max }\right)$
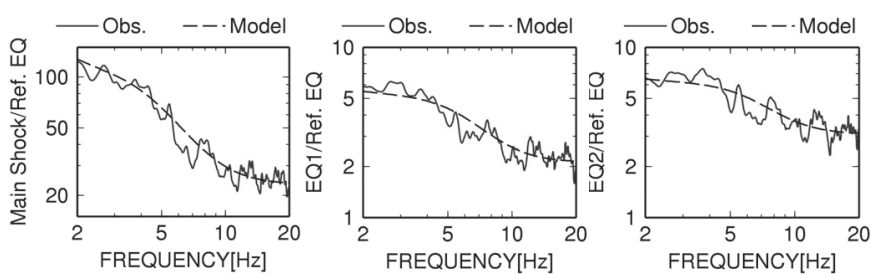

Fig.3 Observed and modeling spectral ratios of acceleration source spectra of the main shock, EQ1, and EQ2 to Ref. EQ

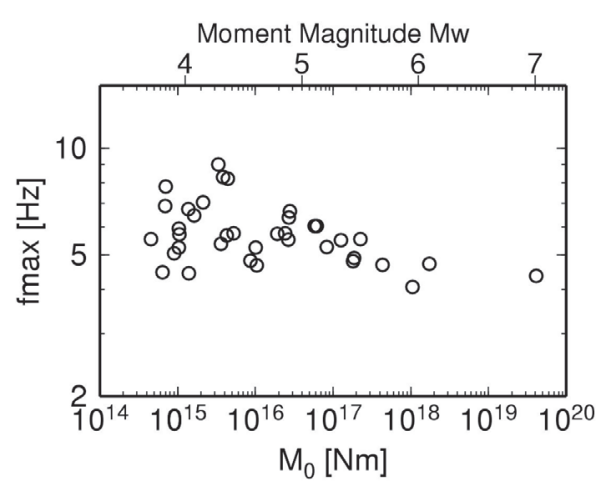

Fig.4 $M_{0}-f_{\max }$ relation for 37 earthquakes around the source region of the 2016 Kumamoto earthquake 
を示す。モデルは観測のスペクトル比をほぼ再現している。本震の $f_{\max }$ は $4.4 \mathrm{~Hz}$ である。一方、ほぼ同規模の 1995 年兵庫県南部地震 22)では $f_{\max }=6 \mathrm{~Hz} 、 n=3.1 、 2010$ 年鳥取県西部地震 16)では $f_{\max }=6.1 \mathrm{~Hz}$ 、 $n=1.2$ である。本震の $f_{\max }$ はこれらに比べ小さく、 $n=4$ と設定して いるため、短周期レベルに対する高周波数での震源スペクトルレベ ルが小さいことを意味する。Fig.4 には、37 地震の $f_{\max }$ と $M_{0}$ の関 係を示す。 $M \mathrm{w} 6$ 以上の 3 つの地震の $f_{\max }$ は $4 \sim 5 \mathrm{~Hz}$ と小さく、 $M_{0}$ が小さくなると $f_{\max }$ の大きい地震が増える傾向がみられる。2000 年鳥取県西部地震とその余震では地震規模依存性がほとんどないこ とが指摘されており 16)、異なる特徵がある。

\section{3. 広帯域震源モデル推定に用いるデータと手法}

\section{（1）データ及び観測波形の補正方法}

Fig. 5 に、本震と 2 つの要素地震の震央位置・ CMT 解、強震動生 成域の探索領域、用いる観測点位置を示寸。震源近傍の 6 つの KiK-net 観測点(地中) と、震源を取り囲む 12 の-NET 観測点の水 平成分を対象とした。本震が $M \mathrm{w} 7.1$ であることから、要素地震と

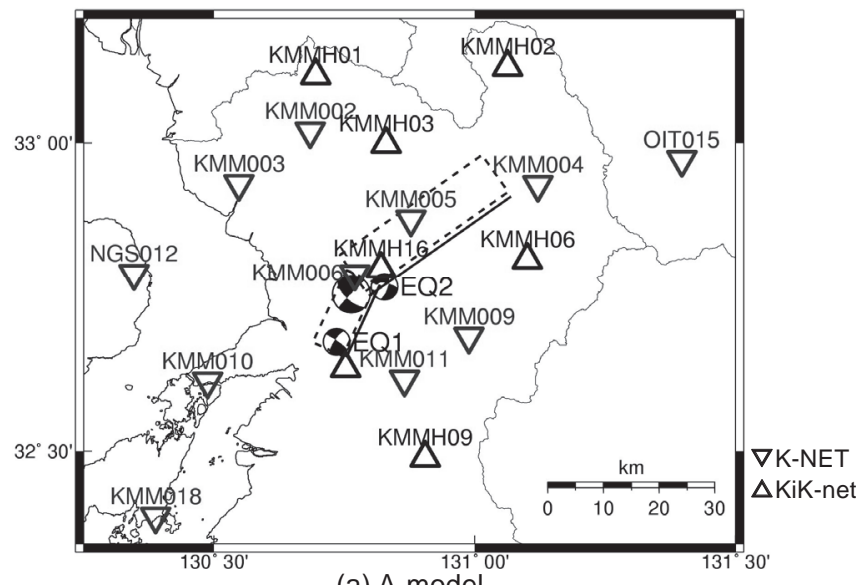

(a) A-model

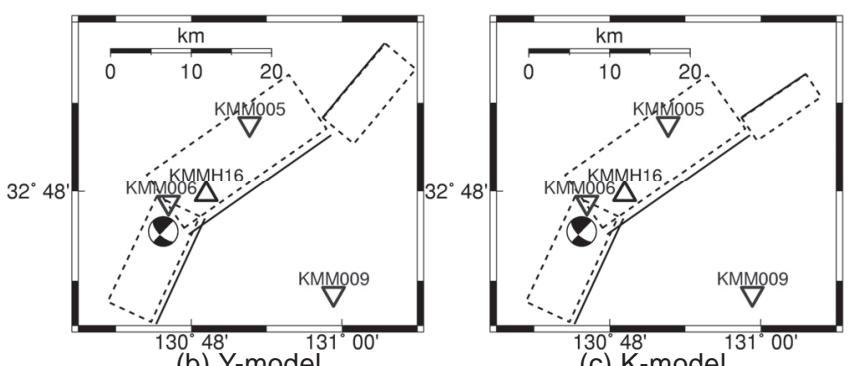

(b) $Y$-model

(c) K-model

Fig.5 Epicenters and CMT solutions of the main shock and two element earthquakes with the location of strong motion stations used for the empirical Green's function method (Two dashed squares denote the region searching SMGAs. Bold lines denote surface traces of the searching regions.)

Table2 Regions searching SMGAs

\begin{tabular}{|c|c|c|c|c|c|c|}
\hline & \multicolumn{3}{|c|}{ Northeast Shallow Corner } & \multirow{2}{*}{\begin{tabular}{|c|} 
Strike \\
$/$ Dip \\
{$\left[{ }^{\circ}\right]$}
\end{tabular}} & \multirow{2}{*}{$\begin{array}{c}\text { Length } \\
\text { /Width } \\
{[\mathrm{km}]}\end{array}$} \\
\hline & & $\begin{array}{c}\text { Longitude } \\
{\left[{ }^{\circ}\right]}\end{array}$ & $\begin{array}{c}\text { Latitude } \\
{\left[{ }^{\circ}\right]}\end{array}$ & $\begin{array}{l}\text { Depth } \\
{[\mathrm{km}]}\end{array}$ & & \\
\hline Hinag & fault & 130.812 & 32.772 & 2.1 & $205 / 72$ & $14.4 / 19.2$ \\
\hline \multirow{5}{*}{$\begin{array}{l}\text { Futagawa } \\
\text { fault }\end{array}$} & A-model & 131.064 & 32.921 & 2.1 & $235 / 65$ & $31.2 / 19.2$ \\
\hline & \multirow{2}{*}{ Y-model } & 130.979 & 32.871 & 2.1 & $235 / 65$ & $21.6 / 19.2$ \\
\hline & & 131.058 & 32.966 & 0.2 & $40 / 75$ & $12.0 / 19.2$ \\
\hline & \multirow{2}{*}{$\mathrm{K}$-model } & 130.979 & 32.871 & 2.1 & $235 / 65$ & $21.6 / 19.2$ \\
\hline & & 131.060 & 32.931 & 0.2 & $56 / 62$ & $9.6 / 7.2$ \\
\hline
\end{tabular}

しては、中間周期帯域の落ち込みを防ぐため、 $M \mathrm{w} 5$ クラスの地震 を選択した。南の日奈久断層側では Table1の EQ1 を、北の布田川 断層側では $\mathrm{EQ} 2$ を用いている。 $\mathrm{EQ} 1 、 \mathrm{EQ} 2$ のコーナー周波数は、 それぞれ、 $0.96 \mathrm{~Hz} 、 0.99 \mathrm{~Hz}$ である。このコーナー周波数から算出 される EQ1、EQ2 の断層面積に基づき、経験的グリーン関数法 23$)$ で用いる要素断層は、 $2.4 \mathrm{~km} \times 2.4 \mathrm{~km}$ とした。また、Table1に示し た本震と要素地震の $f_{\max }$ の違いでフーリエ振幅を補正した波形を、 要素波として用いる。 $\mathrm{S}$ 波初動の 2 秒前から 30 秒間の波形を用い、 周期 $0.2 \sim 5$ 秒を検討対象とすることから時間刻みは 0.02 秒とした。

強震動生成域の探索範囲は、南の日奈久断層側は、本震の気象庁 の震源が断層面に載るように、Asano and Iwata')を参考に設定し、 北の布田川断層側は以下の 3 ケースの設定を行った。A-model は、 Asano and (wata ${ }^{1)}$ を参考にした北西傾斜の断層面であり、Y-model と K-model は、A-model の西側部分の断層面に、地殼変動等に基づ き推定されている南東傾斜の断層面 12),13)を考慮したモデルである。 この領域は、余震がほとんど発生していない Aso gap と呼ばれる領 域 24)であるため、走向や傾斜がやや異なる 2 つのモデルを仮定して いる。Y-model は、Yoshida et al.4)やYoshida et al.が参照している Ozawa et al. ${ }^{13)}$ を参考に、K-model は Kato et al.12)を参考にして、 要素地震のサイズに合うやや大きめの範囲を設定した。図中の太実 線は、強震動生成域の探索範囲と同じ傾斜角を仮定して延長した場 合の地表トレースである。Table2 に、強震動生成域の探索範囲をま とめて示す。なお、Ozawa et al. ${ }^{13)}$ や最新の Kobayashi et al. ${ }^{25)}$ の研 究では、地款変動データ等に基づき、布田川断層側の主断層にほぼ 平行で、やや傾斜角の異なる断層面も仮定し、その断層面では正断 層成分が卓越していることを指摘している。震源域にこのようなメ カニズムの違いを考慮できる適切な余震がなく、2つの平行断層の 距離が非常に近いことから、経験的グリーン関数法で両断層を区別
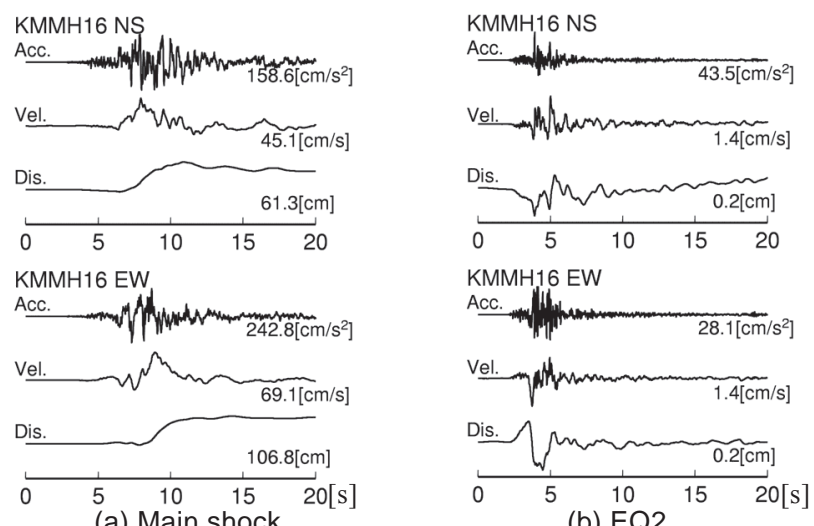

Fig.6 Waveforms observed at KMMH16(borehole)
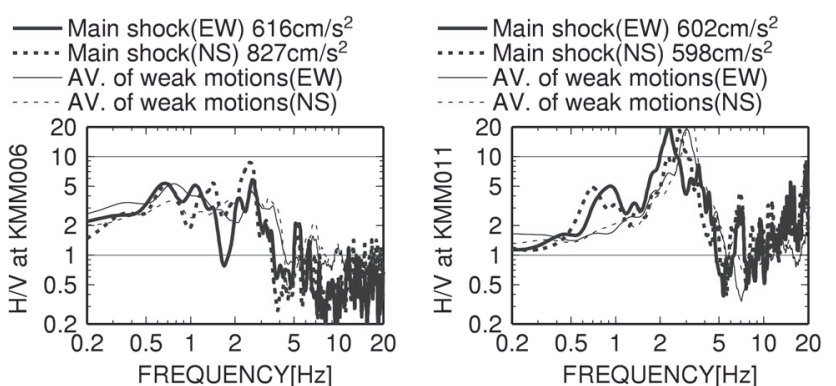

Fig.7 $\mathrm{H} / \mathrm{V}$ of the main shock and the average $\mathrm{H} / \mathrm{V}$ of the weak motions used in the spectral inversion ${ }^{14), 15)}$ at two stations 
するのは困難と考え、検討対象とはしない。

Fig.6 には、KMMH16 地中(益城)での本震と EQ2 の観測波形を 示寸。加速度波形から速度波形、変位波形を算出する際には、基線 補正後、Katukura and Hayashi ${ }^{26)}$ の因果的 FFT 解析手法を用いて 永久変位も求めている。フィルター処理は行っていないため、EQ2 の NS 成分の変位波形には長周期ノイズの影響がみられる。本震の 波形には、近地項・中間項の特徵がみられ、永久変位が生じている。

$\mathrm{EQ} 2$ の波形にも、 $\mathrm{P}$ 波と $\mathrm{S}$ 波到達の間に、近地項の影響とみられる 成分が生じているが、 $\mathrm{EW}$ 成分の速度波形の形状は本震の波形に類 似している。震源近傍では、他の本震の波形にも近地項 - 中間項が みられており、これについては、後で考察する。

震源近傍の記録は重要であることから用いた K-NET の記録には、 地盤の非線形性の影響があるものも含まれている。Fig.7 には、2 観測点での本震の $\mathrm{H} / \mathrm{V}$ と、スペクトルインバージョンで用いている 弱震動 ${ }^{15)}$ の $\mathrm{H} / \mathrm{V}$ の平均值の比較を示す。本震の $\mathrm{H} / \mathrm{V}$ のピークが低 周波数側にやや移動しており、地盤の非線形性の影響と考えられる。 そこで、弱震動の $\mathrm{H} / \mathrm{V}$ の平均值に対する本震の $\mathrm{H} / \mathrm{V}$ の比を、経験 的グリーン関数法による計算波の NS、EW 成分、それぞれのフー リエ振幅に乗じることで、地盤の非線形性の影響を補正する。上下 動には地盤の非線形性はほとんどみられないことから、これまで、 強震動と弱震動の $\mathrm{H} / \mathrm{V}$ の違いから、地盤の非線形性を分析する検討 が行われている例えは2 27)。さらに、小林・儘田 28 は、数值実験及び観 測データに基づき、強震動と弱震動の $\mathrm{H} / \mathrm{V}$ の比を用いた非線形時の 地盤同定手法の妥当性を示している。本震と弱震動として用いた地 震のラディエーションパターン、伝播経路が異なればその影響が出 ると考えられるが、これは、経験的グリーン関数法に対しても言え ることであり、本質的な問題にはならないと考えられる。

\section{（2）広帯域震源モデルの推定手法}

はじめに、A-model で広帯域震源モデルを推定する。次に、 A-modelの日奈久断層側と布田川断層側の西側部分の推定震源モデ ルを用いて、Y-model と K-model の南東傾斜の断層面内の強震動生 成域と破壊開始点を推定する。 SMGA は、日奈久断層側に 1 つ、北 西傾斜の布田川断層側に 3 つ、南東傾斜の布田川断層側に 1 つと仮 定した。北西傾斜の布田川断層側に 2 つ仮定した検討も行ったが、 再現性が良くなかったため 3 つ増やした。背景領域は考慮しない。
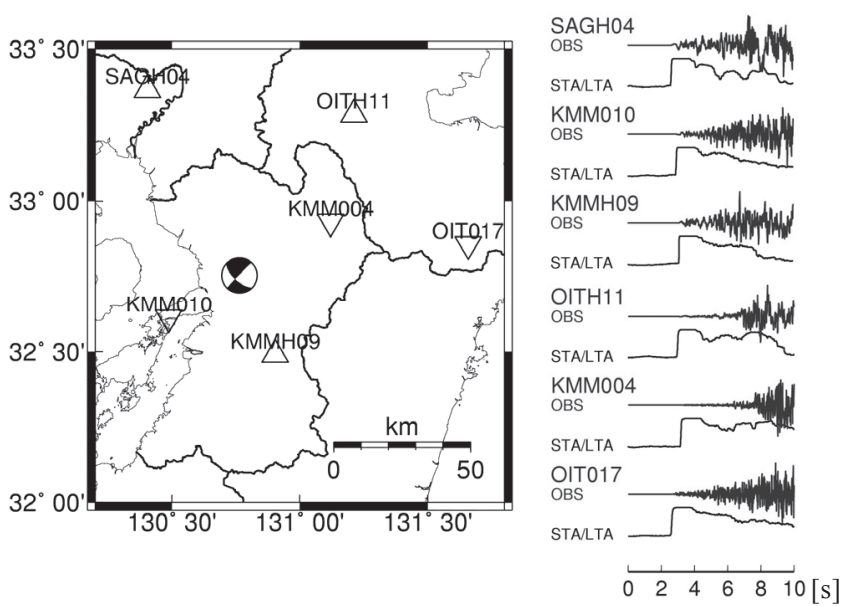

Fig.8 Acceleration records and STA/LTA of vertical components around the $\mathrm{P}$-wave arrival (right) with the location of the strong motion stations and the epicenter of the main shock (left)
経験的グリーン関数法に基づく検討に先立ち、日奈久断層側の SMGA1 の破壊開始位置と時間を、 $\mathrm{P}$ 波初動前から $\mathrm{S}$ 波初動後まで の加速度波形の上下成分の STA/LTA ${ }^{9}$ にに基づき推定する。LTA(Long time average)のウィンドー幅を 10 秒、STA(Short time average) の幅を 1 秒とした。この検討には、震源距離 $100 \mathrm{~km}$ 以内の KiK-net(地中)、K-NET 観測点を用いているが、Fig.8 には、例と して 6 観測点での STA/LTA と観測加速度波形を示す。 $\mathrm{P}$ 波到達前 である震源距離 $[\mathrm{km}] / 5.8[\mathrm{~km} / \mathrm{s}]-3[\mathrm{~s}]$ からの 10 秒間である。STA/LTA は、 $\mathrm{P}$ 波初動で急激に立ち上がり、その約 1 秒後に波群の到来によ り減少している。また、 $\mathrm{P}$ 波初動と次の波群到来までの時間が、到 来方向にほとんど依存しないことがわかる。要素断層が $2.4 \mathrm{~km}$ 角の 正方形であるため、SMGA1 は震源と同じ位置で 1 秒後に破壊し、

同心円状に伝播したと設定した。

北西傾斜の布田川断層側の SMGA2 と SMGA4 の破壊開始位置と 時間は、経験的グリーン関数法によるフォワードモデリングで推定 する。SMGA2 と SMGA4 とも、それぞれの破壊開始点から同心円 状に破壊し、SMGA3 は、SMGA2 の破壊開始位置から同心円状に 破壊すると仮定した。SMGA 破壊開始点からの破壊伝播速度は、日 奈久断層側と布田川断層側の 2 種類を設定する。

強震動予測レシピ 20)では、震源域の詳しい情報がない限り各アス ペリティの応力降下量は同じと仮定することから、推定パラメータ 数を減らすため、各 SMGA の応力降下量 $\Delta \sigma_{a}$ は同じと仮定した。こ の場合 SMGA 全体の短周期レベル $A$ は、次式で表される。

$$
A=4 \sqrt{\pi} \beta^{2} \Delta \sigma_{a} \sqrt{S_{a}}
$$

ここで、 $\beta$ は震源の $\mathrm{S}$ 波速度 $(3.5 \mathrm{~km} / \mathrm{s})$ であり、 $S_{a}$ は $\mathrm{SMGA}$ の総面 積である。 $A$ が既知であれば、SMGA を設定すると $\Delta \sigma_{a}$ が算出され る。そこで、はじめに、佐藤 ${ }^{15)}$ の推定值 $\left(1.58 \times 10^{19} \mathrm{Nm}\right)$ を $A$ の初期 值として経験的グリーン関数法で波形を計算し、H/V で計算波を補 正する。次に、観測と計算の $1 \sim 10 \mathrm{~Hz}$ のフーリエ振幅スペクトルの 比の平均值で $A$ を補正して再度同様の計算を行い、最終結果を得る 29)。なお、実体波の幾何減衰と、佐藤 14$), 15) の Q=62 f 0.87$ を用いて距 離補正を行なう。フォワードモデリングでは、周期 $0.1 〜 5$ 秒の加速 度フィルター波形、周期 $0.1 \sim 5$ 秒の速度フィルター波形を用いた。

既往の研究では、広帯域震源モデルの優劣を定量的に評価するた

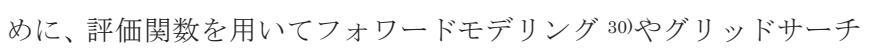

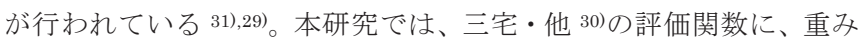
係数を導入した以下の指標 ${ }^{29)}$ で misfit を定義する。

misfit=misfit + +misfit

$$
\text { misfit }_{k}=\sum_{i} \sum_{j} W_{i j k}\left[\sum_{t}\left(O_{k}-S_{k}\right)^{2} /\left\{\left(\sum_{t} O_{k}^{2}\right)\left(\sum_{t} S_{k}^{2}\right)\right\}^{1 / 2}\right]
$$

$O 、 S$ はそれぞれ、観測、シミュレーションを意味する。i、jはそ れぞれ、観測点、成分を意味する添え字である。 $k$ は、 $a$ または $v$ あり、それぞれ、0.1〜 5 秒の加速度フィルター波形のエンベロープ、 0.1〜 5 秒の速度フィルター波形を意味する。エンベロープを求める 際のバンド幅は 0.5 秒とした。近地項・中間項の影響もあることか ら、三宅・他 30)で用いられている変位波形の代わりに速度波形を用 い、 $W_{i j a}$ を $W_{i j V}$ の 8 倍とした。また、 $\mathrm{H} / \mathrm{V}$ の検討に基づき地盤の非 線形性の大きいと考えられた KMM009 と KMM011 のみ、 $W_{i j a}$ を $W_{i j V}$ をさらに 0.5 倍した。Y-model の最適值の場合の misfita と 
misfit の比は、 5 対 4 程度となっている。 $t$ は時間であり、 $\mathrm{S}$ 波初 動の 2 秒前から 20 秒間を用いた。そして、グリッドサーチにより、 misfit が最小になる南東傾斜の断層面内の破壊開始点と、SMGA5 の位置、大きさを推定する。SMGA4 と SMGA5 の破壊時間差は、 両地点の距離と布田川断層側の破壊伝播速度から算出し、SMGA5 の破壞開始点からの同心円状破壊を仮定した。また、破壊開始点は SMGA5 内の外側のグリッドという制限を設けた。

\section{4. 広帯域震源モデルと強震動の推定結果}

（1）広帯域震源モデル

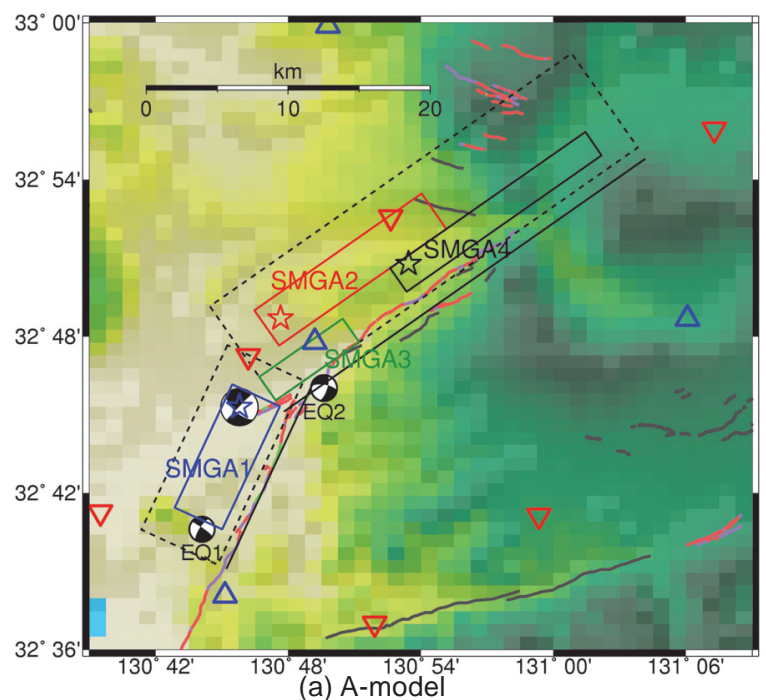

Fig.9には、A-model と、misfitが最小となった Y-model の SMGA の位置と破壊開始点の位置を示寸。Y-model の misfitの值は 169.8 である。一方、A-model、K-model の misfit は、それぞれ 170.9、 173.9 であった。中田・今泉 ${ }^{32)}$ の既存の活断層位置、国土地理院 ${ }^{33)}$ による標高も示している。Y-model の SMGA5 の位置と A-model の SMGA4 の北東部の位置は平面的には類似しており、阿蘇のカル デラ内の北西部まで伸びている。SMGA5 の位置は、余震の少ない Aso gap と呼ばれる領域 24)にある。布田川断層の北西傾斜断層面で は西側の SMAG2 がやや深く東側の SMGA4 がやや浅いという特徵 は、Asano et al.1)、Kubo et al.2)、引間 3)、Yoshida et al.4)のすべり

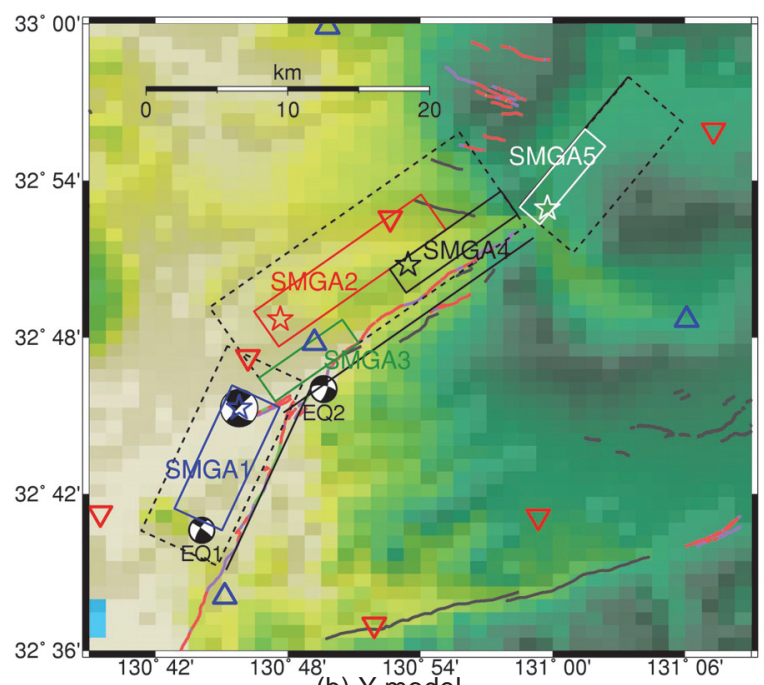

Fig.9 Estimated broadband source model (stars: rupture starting points) with the elevation ${ }^{33)}$, active faults ${ }^{32)}$ (red: active fault trace, violet: active fault trace (site indistrict), green: active fault trace (concealed), grey: active faults estimated) and strong motion stations ( $\triangle:$ KiK-net, $\nabla: \mathrm{K}-\mathrm{NET})$

(a) A-model

\begin{tabular}{|c|c|c|c|c|c|c|}
\hline & $\begin{array}{c}\text { Length } \\
/ \text { Width } \\
{[\mathrm{km}]}\end{array}$ & $\begin{array}{c}S_{a} \\
{\left[\mathrm{~km}^{2}\right]}\end{array}$ & $\begin{array}{c}\Delta \sigma_{a} \\
{[\mathrm{MPa}]}\end{array}$ & $M_{0}[\mathrm{Nm}]$ & $\begin{array}{r}\text { Rupture } \\
\text { Starting } \\
\text { Time[s] }\end{array}$ & $\begin{array}{l}\text { Rupture } \\
\text { Velocity } \\
{[\mathrm{km} / \mathrm{s}]}\end{array}$ \\
\hline SMGA1 & $9.6 / 12.0$ & 115.20 & 10.0 & $5.05 \mathrm{E}+18$ & 1.0 & 2.4 \\
\hline SMGA2 & $14.4 / 7.2$ & 103.68 & 10.0 & $4.31 \mathrm{E}+18$ & 3.3 & 2.8 \\
\hline SMGA3 & $7.2 / 4.8$ & 34.56 & 10.0 & $8.30 \mathrm{E}+17$ & & 2.8 \\
\hline SMGA4 & $16.8 / 4.8$ & 80.64 & 10.0 & $2.96 \mathrm{E}+18$ & 6.7 & 2.8 \\
\hline
\end{tabular}

(b) Y-model

\begin{tabular}{|c|c|c|c|r|r|r|}
\hline & $\begin{array}{c}\text { Length } \\
\text { Width } \\
{[\mathrm{km}]}\end{array}$ & $\begin{array}{c}S_{a} \\
{\left[\mathrm{~km}^{2}\right]}\end{array}$ & $\begin{array}{c}\Delta \sigma_{a} \\
{[\mathrm{MPa}]}\end{array}$ & $M_{0}[\mathrm{Nm}]$ & $\begin{array}{l}\text { Rupture } \\
\text { Starting } \\
\text { Time[s] }\end{array}$ & $\begin{array}{l}\text { Rupture } \\
\text { Velocity } \\
{[\mathrm{km} / \mathrm{s}]}\end{array}$ \\
\hline SMGA1 & $9.6 / 12.0$ & 115.20 & 11.5 & $5.86 \mathrm{E}+18$ & 1.0 & 2.4 \\
\hline SMGA2 & $14.4 / 7.2$ & 103.68 & 11.5 & $5.00 \mathrm{E}+18$ & 3.3 & 2.8 \\
\hline SMGA3 & $7.2 / 4.8$ & 34.56 & 11.5 & $9.62 \mathrm{E}+17$ & & 2.8 \\
\hline SMGA4 & $9.6 / 4.8$ & 46.08 & 11.5 & $1.48 \mathrm{E}+18$ & 6.7 & 2.8 \\
\hline SMGA5 & $7.2 / 7.2$ & 51.84 & 11.5 & $1.77 \mathrm{E}+18$ & 10.6 & 2.8 \\
\hline
\end{tabular}

Averege for crustal earthquakes(Dan et al.,2001)

- Averege \pm Standard deviation(Satoh,2010)

Averege for Strike-slip fault(Satoh,2010)

- Main shock (This study by EGF:A-model)

Main shock (This study by EGF:Y-model)

037 earthquakes(Satoh,2016)

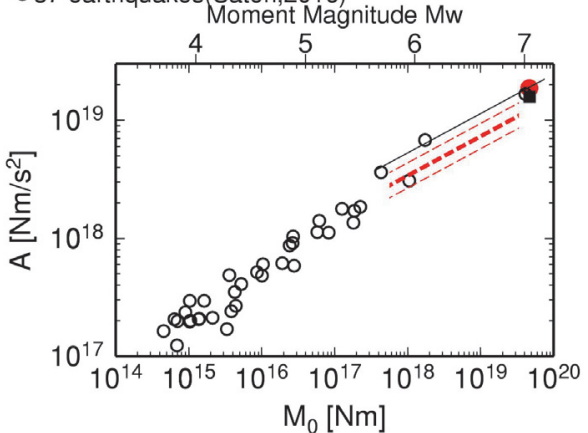

Fig.10 $\mathrm{M}_{0}-\mathrm{A}$ relation for 37 earthquakes around the 2016 Kumamoto earthquake source region estimated by Satoh ${ }^{15)}$ and for the main shock in this study

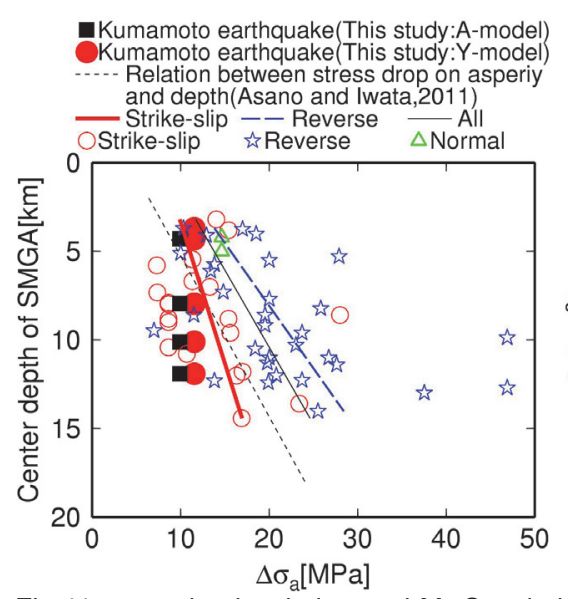

- Kumamoto earthquake(This study:A-model) Kumamoto earthquake(This study:Y-model) Relation between $\mathrm{M}_{\mathrm{p}}$ and total area of asperity(Somerville et al.,1999) OStrike-slip is Reverse $\triangle$ Normal Moment Magnitude Mw

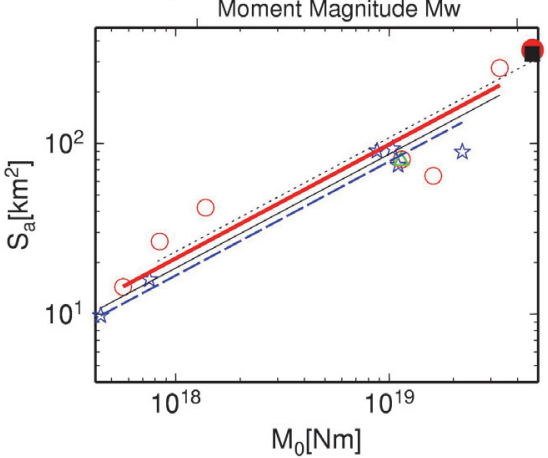

Fig.11 $\Delta \sigma_{a}$-depth relation and $M_{0}-S_{a}$ relation of the main shock in this study and the previous crustal earthquakes shown in Satoh and Okazaki ${ }^{38)}$ 
量分布の特徴とほぼ対応している。詳細にみると、SMGA4 の深さ は、Yoshida et al.4)のすべり量が大きい領域よりモーメントレイト が大きい領域との整合性が良く、短周期の方が長周期よりやや深い 領域で励起されたものと考えられる。既往の波形インバージョンで は、日奈久断層側の震源周辺でのす心゙り量は、布田川断層側のす心゙ り量に比心゙相対的に小さいが、日奈久断層側に比較的サイズの大き な SMGA1 が推定されている。

Table3 には推定震源パラメータを示す。SMGAの $M_{0}$ は、円形ク ラックの式 ${ }^{34}$ に基づき算出した。最適モデルである Y-model の SMGA の応力降下量 $\Delta \sigma_{a}$ は $11.5 \mathrm{MPa}$ であり、 Irikura et al.7)の 2 種 類のモデルの $13.4 \sim 13.9 \mathrm{MPa}$ と比べやや小さいが、入倉・三宅 ${ }^{40)}$ の平均的な特性化震源モデルと同レベルである。SMGA の総面積 $S_{a}$ は $351.36 \mathrm{~km}^{2}$ であり、Irikura et al. ${ }^{7)}$ の 2 種類のモデルの 1.5 倍 程度である。短周期レベル $A=1.88 \times 10^{19} \mathrm{Nm}$ は、Irikura et al. ${ }^{7}$ の 2 種類のモデルの $1.58 \times 10^{19} \mathrm{Nm} 、 1.71 \times 10^{19} \mathrm{Nm}$ や、スペクトル インバージョンに基づく佐藤 $\left.{ }^{15}\right)\left(1.58 \times 10^{19} \mathrm{Nm}\right)$ や内山・山本 ${ }^{35)}$ の 推定值 $\left(1.50 \times 10^{19} \mathrm{Nm}\right)$ よりやや大きい程度で違いは小さい。また、 SMGA2 から SMGA4 までの破壊伝播時間 3.4 秒は、SMGA2 の破 壞開始点から SMGA4 の破壊開始点まで同心円状破壊をした場合、 破壊伝播速度 $3.1 \mathrm{~km} / \mathrm{s}$ に相当する。引間 ${ }^{3)}$ は、この領域付近で局所 的に $3.2 \mathrm{~km} / \mathrm{s}$ 程度の破壞伝播速度であった可能性を指摘しており、 本研究の結果はこれとほぼ整合する。破壊伝播速度は、布田川断層 側では $2.8 \mathrm{~km} / \mathrm{s}$ と、Irikura et al. ${ }^{7)}$ と同じである。日奈久断層側で
は $2.4 \mathrm{~km} / \mathrm{s}$ とやや遅い。SMGA1 から SMGA2 までの破壊伝播時間 3.3 秒は、SMGA1の破壊開始点から SMGA2 の破壊開始点までの 距離 $7.8 \mathrm{~km}$ を用いると破壊伝播速度 $2.3 \mathrm{~km} / \mathrm{s}$ に相当する。

Fig.10には、Y-model と A-model の短周期レベル $A$ と $M_{0}$ との関 係を、佐藤 15)のスペクトルインバージョンに基づく 37 個の地震及 び地款内地震に対する既往の関係式 36),37) と比較した結果を示す。

Fig.10、11 の本震の $M_{0}$ は、Yoshida et al.4)の推定値を用いた。

Y-model の $A$ は、壇・他 ${ }^{36)}$ の地款内地震の平均值と同レベルで、佐 藤 37)の横ずれ断層の平均值の約 1.5 倍である。

Fig.11は、日本の地殼内地震に対して推定されている広帯域震源 モデルの SMGA の応力降下量 $\Delta \sigma_{a}$ と中心深さの関係 ${ }^{38)} 、 M_{0}$ と SMGA の総面積 $S_{a}$ の関係 ${ }^{38}$ に、本研究の推定值を加筆したもので ある。本研究では、各 SMGA の応力降下量を同じと仮定している ため、深さ依存性がないが、Y-model は、地款内地震としてはやや 小さく、横ずれ断層としては平均に近い。Y-model では、 $S_{a}$ は、 Somerville et al. ${ }^{39)}$ の地殼内地震のアスペリティの総面積の 1.16 倍 である。また、Satoh and Okazaki ${ }^{38)}$ の横ずれ断層の $S_{a}$ の平均值 より 1.27 倍大きいが、平均十標準偏差が平均の 1.5 倍であり、得ら れた結果は平均十標準偏差より小さい。同規模の横ずれ断層の 2000 年鳥取県西部地震 $\left(M_{\mathrm{J}} 7.3\right)$ とは、ほぼ同じスケーリングである。

Fig.10、11 とも、A-model でも、Y-model とほぼ同じ特徴がある。 また、Irikura et al. ${ }^{7}$ の推定值とやや異なるものの、地款内地震と しては平均的という特徵は同じである。

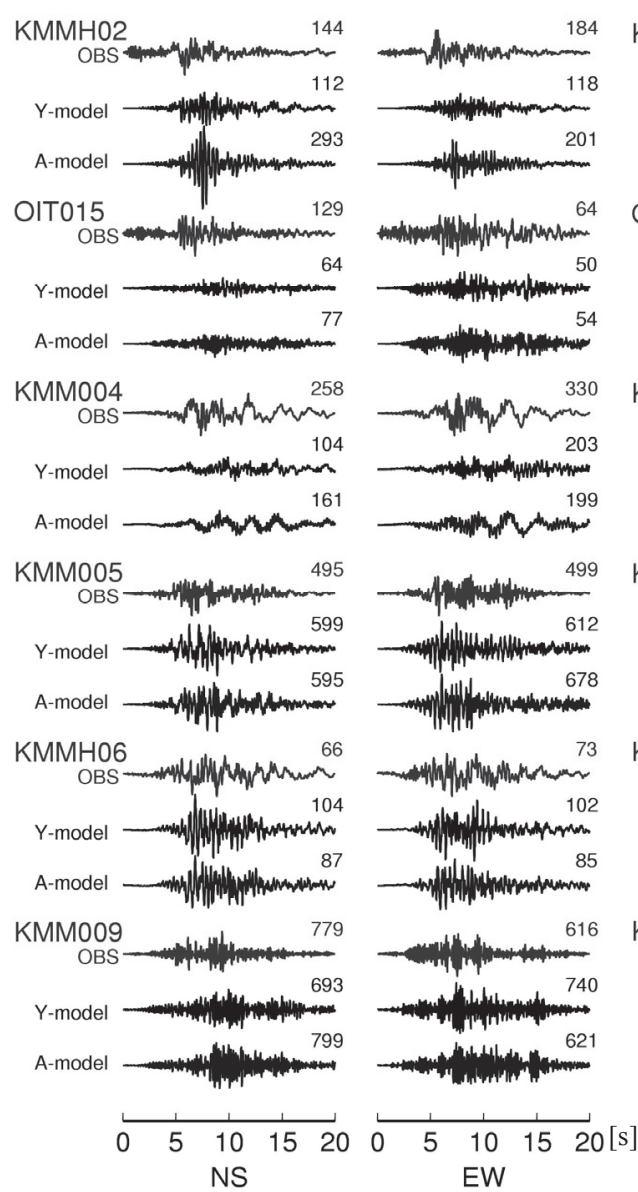

(a) 0.1 to $5 \mathrm{~s}$ band-pass filtered acceleration

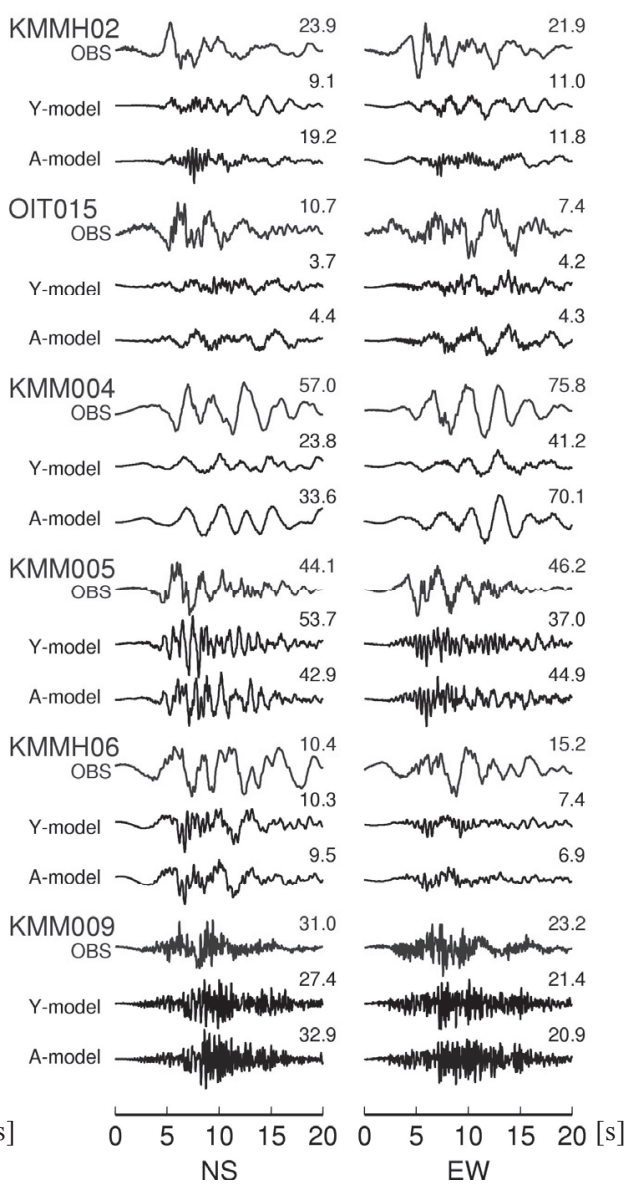

(b) 0.1 to $5 \mathrm{~s}$ band-pass filtered velocity

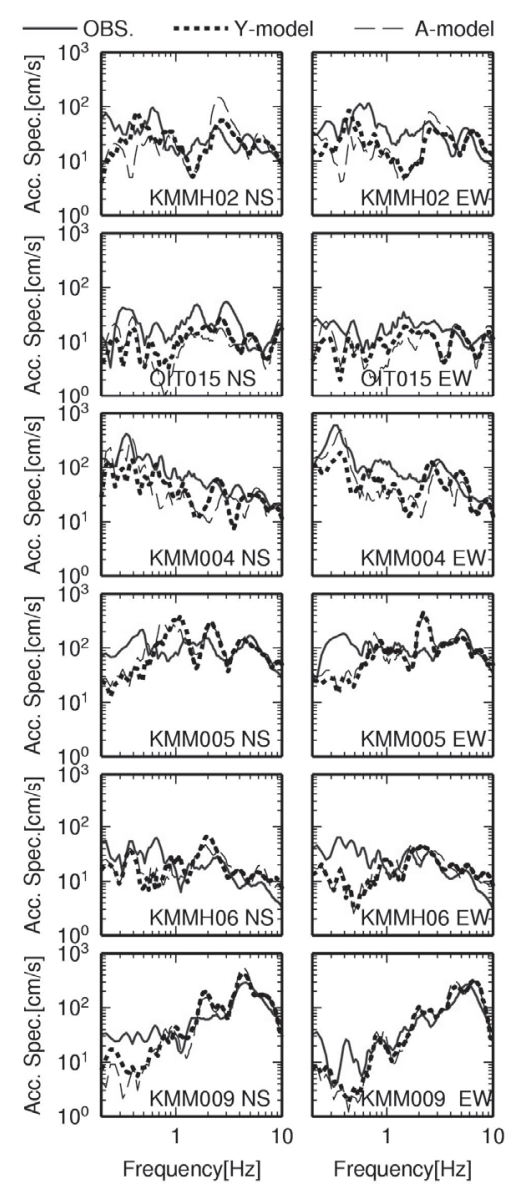

(c) Acceleration Fourier spectra

Fig.12 Observed and synthetic waveforms and acceleration Fourier spectra for Y-model and A-model at six stations in the western region near Mt. Aso (Maximum amplitude is shown above each waveform in $\mathrm{cm} / \mathrm{s}^{2}$ for acceleration and $\mathrm{cm} / \mathrm{s}$ for velocity) 


\section{（2）再現強震動}

Fig.12 には、観測波と Y-model とA-model の計算波の波形と加 速度フーリエスペクトルの比較を示す。南東傾斜の断層に近い 6 観 測点の $\mathrm{S}$ 波到達 2 秒前から 20 秒間の波形である。以降示寸波形は、 周期 $0.1 \sim 5$ 秒の加速度フィルター波、周期 $0.1 \sim 5$ 秒の速度フィル ター波であり、観測波の最大值で基準化して表示している。断層の 北側の KMMH02 では、Y-model が A-model より明らかに観測波の 再現性がよい。また、断層の南側の KMM009 でも、Y-model が A-model より観測波の再現性がややよい。一方、東側の KMM004 やOIT015 では、Y-model の方が A-model より長周期でやや過少評 価となっている。Yoshida et al.4)の波形インバージョンによる震源 モデルでも、南東傾斜と北東傾斜の場合の寸べり量分布の違いは小 さく、resolution も小さいことが述べられている。しかし、北西傾 斜より南東傾斜の震源モデルを用いて計算される変位の方が地殼変

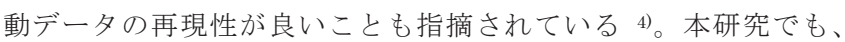

A-model と Y-model の違いは小さいが、misfitが Y-model の方が小 さく、地殼変動などで推定されている断層が南東傾斜であることか ら、Y-model の方が妥当と考えられる。

Fig.13 には、他の西側の 12 観測点での観測波と Y-model の計算 波の比較を示す。北側の観測点の速度波形はやや過少評価であるが、 他の観測点では計算波は観測波をほぼ再現している。Kubo et al. ${ }^{2}$ の波形インバージョンによる計算波も、本研究と共通の北側の観測 点である KMM002、KMM003、KMMH02、KMMH03 では、水平 成分の最大速度が $0.36 \sim 0.66$ 倍と過小評価となっている。Asano and Iwata ${ }^{1)}$ 、引間 ${ }^{3)}$ 、Yoshida et al.4)の波形インバージョンによる 計算波には最大速度值が記述されていないが、本研究と共通の KMMH03 の水平 2 成分、KMMH02 の NS 成分など北側の観測点 の速度波形は過小評価である。過小評価の原因として、本研究も波 形インバージョンでも破壊性状に仮定が入っており、実際の複雑な 破壊性状が表現しきれていないことが可能性として考えられる。
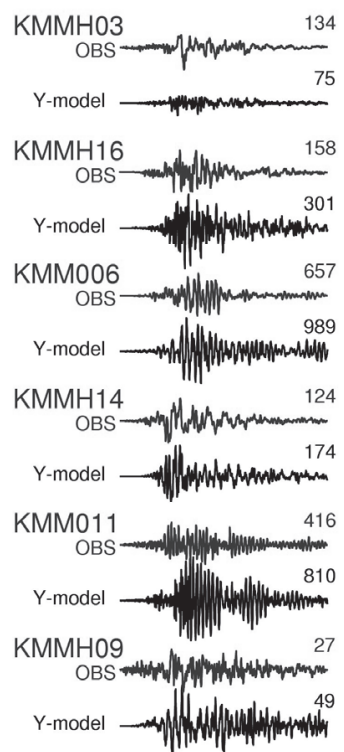

$\mathrm{KMMHO} 1$
$\mathrm{OBS}$ mandy

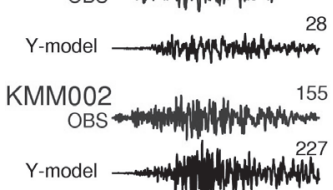

KMMOO3
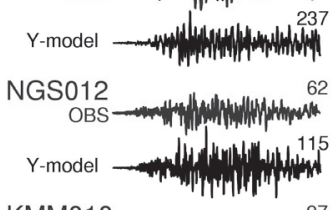

KMM010

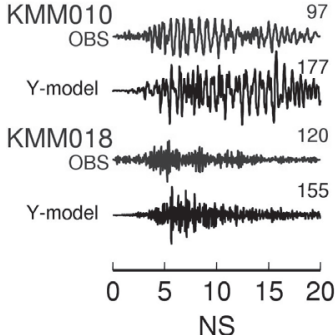

(a) 0.1 to $5 \mathrm{~s}$ band-pass filtered acceleratio
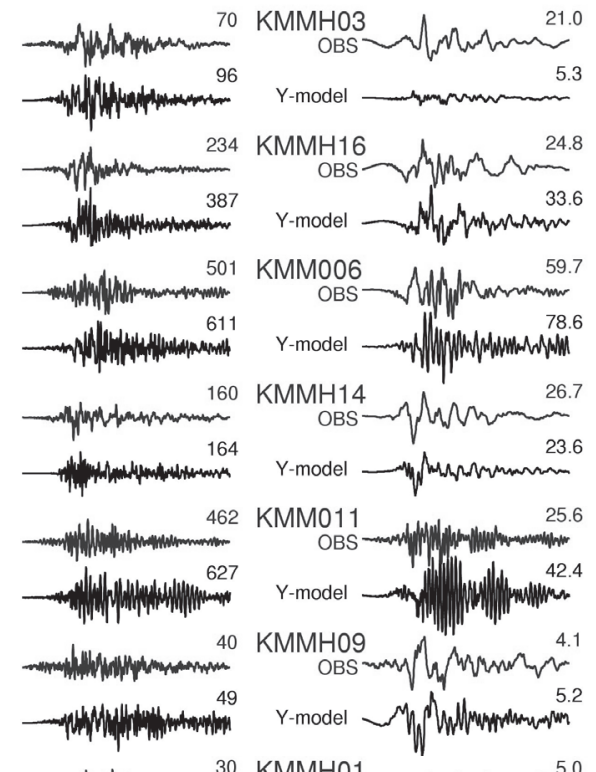

40

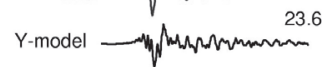

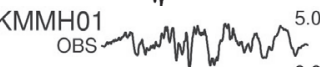

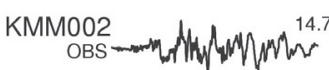

KMMOO3 -

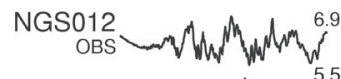

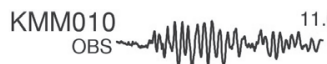

KMM018 18 OBS
OBS 26.7

KMM011

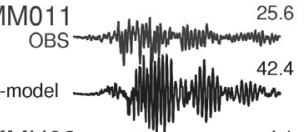

$\mathrm{KMMH09}$

OBS nmy hasumes

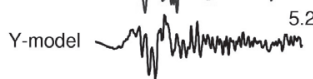

model -umpypmasmansm

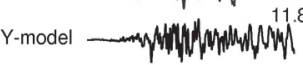

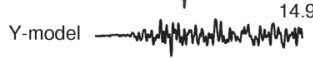

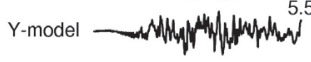

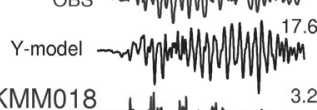

Y-model

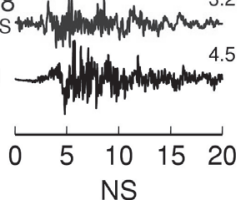

Mhpuniming

TMPrmanom 12.8

Yphon 20.1

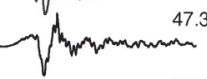

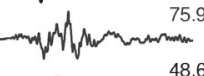

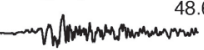

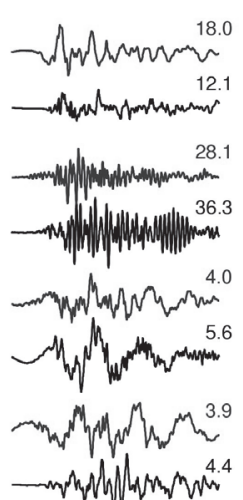

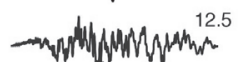

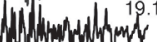
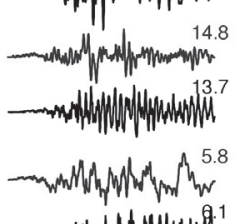

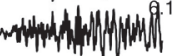
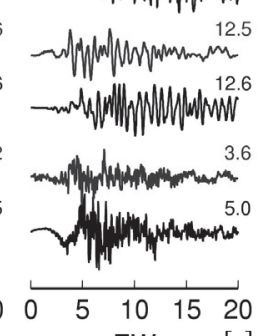

EW [s]

(b) 0.1 to $5 \mathrm{~s}$ band-pass filtered velocity weforms at 12 stations in the eastern region

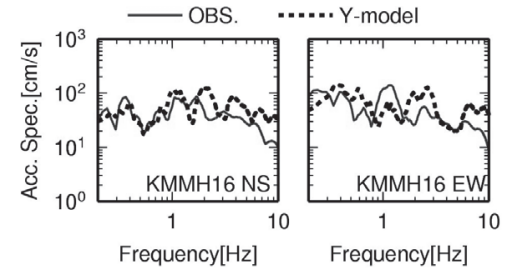

Fig.14 Observed and synthetic (Y-model) acceleration Fourier spectra at KMMH16

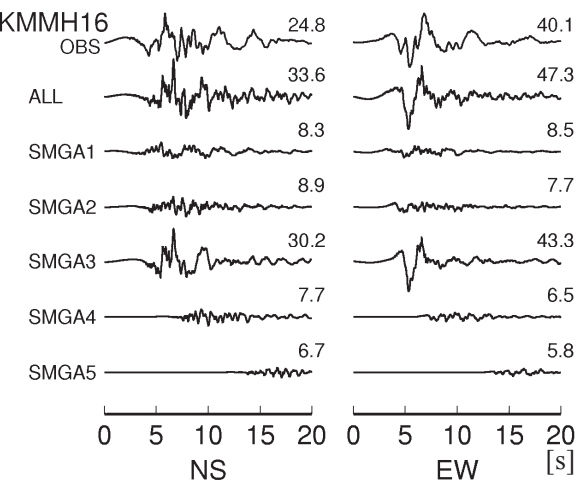

Fig.15 Observed and synthetic (Y-model) waveforms of all SMGAs and each SMGA for 0.1 to $5 \mathrm{~s}$ band-pass filtered velocity at $\mathrm{KMMH} 16$

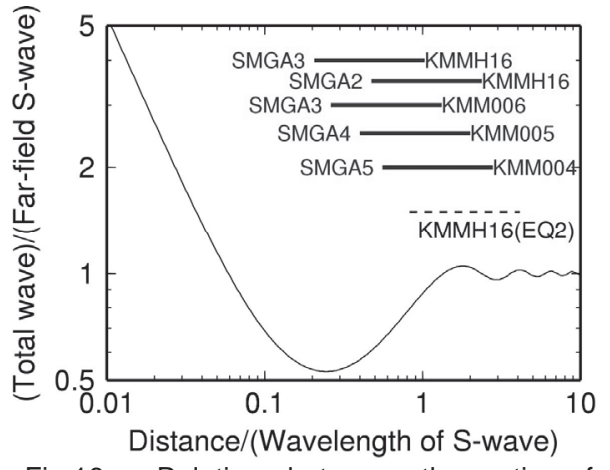

Fig.16 Relation between the ratio of distance to wavelength of S-wave and the ratio of total wave to far-field S-wave ${ }^{41)}$. Bold lines denote the range for the period of 1 to $5 \mathrm{~s}$ for the SMGA. A dashed line denotes the range for the period of 1 to $5 \mathrm{~s}$ for EQ2. 


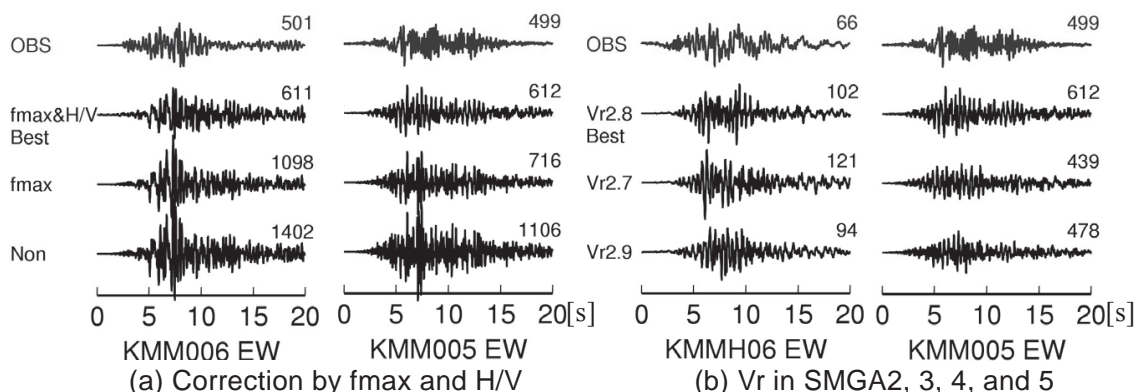

Fig.17 Observed and synthetic (Y-model) waveforms for 0.1 to $5 \mathrm{~s}$ band-pass filtered acceleration

KMM011 は、Fig.7 に示したように地盤の非線形性の影響の大きい 観測点であり、フーリエ振幅は補正したが位相は補正されていない ため、観測の再現性がやや悪いものと考えられる。KMM006 の NS 成分、KMM004 の NS、EW 成分や OIT015 の NS 成分では、速度 パルスはやや過小評価である。経験的グリーン関数を用いた波形イ ンバージョンによる Nozu and Nagasaka6)の周期 0.5〜 5 秒のシミ ュレーションでも、KMM006 の NS 成分、KMM004 の NS、EW 成分の $\mathrm{S}$ 波初動付近の速度パルスは再現されておらず、ラディエー ションパターンや近地項・中間項の影響が原因として考えられる。

Fig.14 には、KMMH16(益城)での観測波と Y-model の計算波の 加速度フーリエスペクトルの比較を示す。Fig.15には、KMMH16 での観測波と Y-model の各 SMGA からの計算波の速度波形の比較 を示す。計算波の速度波形や $0.2 \sim 5 \mathrm{~Hz}$ のスペクトルは、観測波を ほぼ再現している。また、速度パルスには、浅部の SMGA3 の寄与 が大きいことがわかる。Kubo et al. ${ }^{2}$ の波形インバージョンで、 $\mathrm{KMMH} 16$ の $\mathrm{EW}$ 成分の波形に浅部の寸べり量の寄与が大きいとい う結果と整合する。また、KMMH16 が深部からの破壊伝播方向に あるという結果は、Kobayashi et al. ${ }^{25)}$ の波形インバージョンで、 KMMH16 直下では、同心円状に比べ、KMMH16 に向かう方向に 破壊が進んでいるという指摘とも整合する。

\section{（3）推定精度・感度に関する考察}

前述のように KMMH16 などの観測波には、近地項、中間項の影 響がみられるが、全無限弾性体を仮定しない限り、近地項、中間項、 遠地項の分離はできないため、経験的グリーン関数法で考慮するの は困難である。そこで、野津 ${ }^{41)}$ の提案手法による全無限弾性体にお ける $\mathrm{S}$ 波の遠地項に対する近地項十中間項十遠地項のスペクトル比 を用いて、震源に近い観測点での近地項や中間項の影響について考 察する。Fig.16には、S 波の波長に対する観測点までの距離の比と、 遠地項に対する近地項十中間項十遠地項のスペクトル比の関係を示 す。ポアソン個体を仮定した。実線の範囲は、 $\mathrm{S}$ 波速度 $=3.5 \mathrm{~km} / \mathrm{s}$ から算出される周期 1 5 秒の S 波の波長に対する、観測点と SMGA の要素の最短距離の比である。破線は、EQ2 からの距離を用いた場 合である。本震の KMMH16 では、SMGA3 からの距離を用いた場 合、周期 1 秒では近地項十中間項の影響はほとんどないが、周期 5 秒付近では近地項十中間項を考慮すると遠地項のみの場合の 0.5 倍 程度となる。各 SMGA の応力降下量は同じと仮定していたが、

Fig.14の計算波のスペクトルは $1 \mathrm{~Hz}$ 以下で観測と同レベルである ことを考えると、SMGA3 の応力降下量がやや過大評価の可能性が ある。しかし、KMMH16 では SMGA2 からの距離を用いた場合や $\mathrm{EQ} 2$ にも、縦軸の比が小さくなる傾向の近地項＋中間項の影響もあ

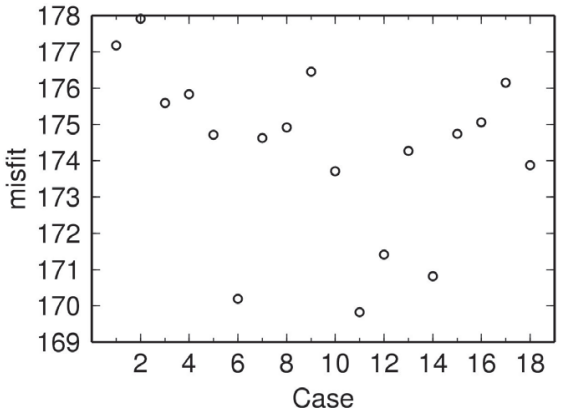

Fig.18 Misfit for 18 cases shown in Table 4 for Y-model
Table4 Number of elements (Strike direction $\times$ dip direction) for SMGA5 in Y-model

\begin{tabular}{|c|c|c|c|c|c|c|c|c|}
\hline Case & $1 \sim 2$ & 3 & $4 \sim 5$ & $6 \sim 7$ & $8 \sim 10$ & $11 \sim 13$ & $14 \sim 15$ & $16 \sim 18$ \\
\hline $\begin{array}{c}\text { Number of } \\
\text { elements }\end{array}$ & $1 \times 2$ & $2 \times 1$ & $2 \times 2$ & $3 \times 2$ & $2 \times 3$ & $3 \times 3$ & $4 \times 2$ & $2 \times 4$ \\
\hline
\end{tabular}

るため、Fig.15 で述べた SMGA3 の寄与が大きいという相対的関係 は変わらない。KMM006、KMM005、KMM004 も周期 5 秒付近の 長周期では近地項十中間項の影響が考えられるが、本研究では、前 述のように加速度エンベロープに重みをつけた評価関数を用いてお り、この影響は軽減されている。

Fig.17(a)、(b)には、 $f_{\max }$ と H/V による補正の有無、布田川断層側 の SMGA2 の破壊開始以降の破壊伝播速度 $V_{r}$ の感度解析結果を示 す。Y-model の場合の、周期 0.1 5 秒の加速度フィルター波である。 (a)は最適震源モデルを用い、(b)では $A$ を観測に整合するように推 定し直している。(a)では、 $f_{\max }$ のみ補正した場合はやや過大評価、 何の補正もない場合にはかなりの過大評価となっており、補正をす る必要があることがわかる。(b)では、misfit が小さい $V r=2.8 \mathrm{~km} / \mathrm{s}$ の場合に、観測の包絡形状の再現性が良いことが確認できる。

Y-model の SMGA5 のサイズと位置を変化させ、それ以外のパラ メータを最適值とした場合の misfitを Fig.18 に示す。Fig.18の横 軸は、SMGA5 のサイズと位置を Table4 の 1〜18 ケースに変化さ せた場合のケース番号を意味する。ケース 11 の場合が最小であり、 これが最適モデルとなっている。ケース 6 の misfitが 2 番目に小さ い。このケース 6 は、ケース 11 の SMGA5 の深部の 3 要素がない ケースであり、短周期レベル、SMGA の応力降下量、SMGA の総 面積は、A-model と同じである。したがって、ケース 6 でも、スケ ーリングに関する結論は変わらない。また、ケース 1～5 は、SMGA5 のサイズが小さいケースであり、サイズが小さいと misfitが大きく なっており、SMGA5 が必要であることがわかる。

\section{5. まとめ}

強震観測記録を用いてスペクトルインバージョンに基づき推定さ れている 2016 年熊本地震の本震を含む $M_{\mathrm{J}} 4.0 \sim 7.3$ の 37 個の震源 域の地震の震源スペクトル ${ }^{15}$ )から $f_{\max }$ を推定した。そして、本震と 2 つの要素地震の $f_{\max }$ の違いと地盤の非線形の影響を補正して、経 験的グリーン関数法 23)を用いたフォワードモデリング及びグリッ ドサーチにより、本震に対する強震動生成域から成る周期 $0.1 \sim 5$ 秒の広帯域震源モデルを構築した。

(1) 本震の $f_{\max }$ は $4.4 \mathrm{~Hz}$ と推定された。同規模の兵庫県南部地震 22)、 鳥取県西部地震 16)に対して推定されている $6 \mathrm{~Hz}$ よりやや小さ 
い。 $f_{\max }$ より高周波数帯域で設定した減衰の傾きは、両地震よ り大きいことも相まって、短周期レベルに対する高周波数での スペクトルレベルが小さい。また、地震規模が小さくなると、 $f_{\max }$ が大きい地震が多くなる規模依存性が認められた。

(2) 阿蘇付近に南東傾斜の断層面を設定した場合と北西傾斜の断 層面のみを設定した場合の観測の再現性の違いは小さかった が、南東傾斜の断層面を設定した場合の方が評価関数による残 差が小さく、これを最適モデルとして選択した。これは、 Yoshida et al. ${ }^{4)}$ の波形インバージョンの結果と同様の傾向で ある。どちらの断層面を仮定した場合でも、平面的な強震動生 成域の位置はほぼ同じで、余震が発生していない領域に位置し、 阿蘇のカルデラ内北西部まで達している。

（3）最適モデルは 5 つの SMGA から成り、SMGA 全体の短周期レ ベルは $1.88 \times \mathrm{Nm} / \mathrm{s}^{2}$ と、壇・他 ${ }^{36)}$ の式とほぼ同じであった。最 適モデルの強震動生成域 SMGA の降下量 $\Delta \sigma_{a}$ は約 $11.5 \mathrm{MPa}$ と 推定され、入倉・三宅 ${ }^{40)}$ の平均的な特性化震源モデルの值と同 レベルであった。SMGAの総面積 $S_{a}$ は、Somerville et al. ${ }^{39}$ の地款内地震の $M_{0}$ とアスペリティ総面積の関係式の 1.16 倍で 平均に近かった。北西傾斜の断層面のみを設定した場合でも、 地殸内地震としては平均的であるという特徴は同じであった。 推定されたパラメータの值は Irikura et al. 7)の広帯域震源モデ ルとやや異なるものの、平均的という特徴は同じである。

（4）布田川断層側の北西傾斜の断層面の北東側の SMGA4 の位置 は、Yoshida et al.4)のすべり量が大きい領域よりモーメントレ イトが大きい領域との整合性が良く、短周期成分の励起領域が 長周期成分よりやや深い領域にあったと考えられる。

（5）日奈久断層の SMGA 内での破壊伝播速度は $2.4 \mathrm{~km} / \mathrm{s}$ 、布田川 断層の SMGA 内での破壊伝播速度は Irikura et al. ${ }^{7)}$ と同じ $2.8 \mathrm{~km} / \mathrm{s}$ と推定された。

（6）ラディエーションパターンや近地項・中間項の影響があるため 定量的ではないが、KMMH16 地中(益城)の速度パルスには、 相対的に直下浅部の SMGA3 の寄与が大きいと考えられる。

\section{謝辞}

本研究は、科学研究費補助金基盤研究(A)26242034(研究代表者川 瀬博教授)による成果である。防災科学技術研究所の K-NET ・ KiK-net の強震記録、F-net の CMT 解、気象庁の 95 型震度計の強 震記録と一元化震源情報を用いました。また、参考文献 32)の製品 シリアル番号 DAFM0334 のデータを用いました。一部の図の作成 には GMT2)を用いました。記して感謝致します。

\section{参考文献}

1) Asano, K. and Iwata, T.: Source rupture processes of the foreshock and mainshock in the 2016 Kumamoto earthquake sequence estimated from the kinematic waveform inversion of strong motion data, Earth, Planets and Space, Vol. 68: 147, doi: 10.1186/s40623 -016-0519-9, 2016. 8

2) Kubo, H. et al.: Source rupture processes of the 2016 Kumamoto, Japan, earthquakes estimated from strong-motion waveforms, Earth, Planets and Space, Vol. 68: 161, doi: 10.1186/s40623-016-0393-5, 2016. 10

3) Hikima, K.: Source rupture process of the 2016 Kumamoto earthquake and its foreshock estimated from strong-motion waveforms, JAEE annual meeting 2016, P4-11, 2016. 9 (in Japanese) 引間和人：強震波形を用いた 2016 年熊本地震の本震・前震の震源過程解 析, 日本地震工学会大会, P4-11, 2016.9

4) Yoshida et al. : Source process of the 2016 Kumamoto earthquake (Mj7.3) inferred from kinematic inversion of strong-motion records Earth, Planets and Space, Vol. 69: 64, doi: 10.1186/s40623-017-0649-8, 2017. 5

5) Shiba, Y.: Source modeling for the 2016 Kumamoto earthquake and its foreshock using empirical Green's function, Fall meeting of 2016 Seismological Society of Japan, S21-P01, 2016. 10 (in Japanese) 芝良昭: 経験的グリーン関数法による 2016 年熊本地震の本震および前震 の震源モデル, 日本地震学会講演予稿集, S21-P01, 2016. 10

6) Nozu, A. and Nagasaka, Y.: Rupture process of the main shock of the 2016 Kumamoto earthquake with special reference to damaging ground motions: Waveform inversion with empirical Green's functions, Earth, Planets and Space, Vol. 69: 22, doi: 10.1186/s40623-017-0609-3, 2017. 1

7) Irikura, K. et al.: Applicability of source scaling relationships for crustal earthquakes to estimation of the ground motions of the 2016 Kumamoto earthquake, Earth, Planets and Space, Vol.69:10, doi: 10.1186/s40623-016-0586-y, 2017. 1

8) Pulido, N.: Super-shear fault rupture during the 2016/04/16 Kumamoto earthquake (Mw7.1) estimated by seismic back-projection and KNET/KiKnet records, Fall meeting of 2016 Seismological Society of Japan, S21-39, 2016. 10

9) Allen, R.: Automatic earthquake recognition and timing from single traces, Bull. Seism. Soc. Am., Vol. 68, pp.1521-1532, 1978.10

10) Shirahama, Y. et al.: Characteristics of the surface ruptures associated with the 2016 Kumamoto earthquake sequence, central Kyushu, Earth, Planets and Space, Vol. 68:191, doi:10.1186/ s40623-016-0559-1, 2016.10

11) Lin, A. et al.: Coseismic rupturing stopped by Aso volcano during the 2016 Mw 7.1 Kumamoto earthquake, Japan, Science, Vol. 354: 6314, pp. 869-874, doi: 10.1126/science.aah4629, 2016. 10

12) Kato, A. et al.: The 2016 Kumamoto earthquake sequence, Proc. Jpn. Acad., Ser. B, Vol. 92, No. 8, pp. 358-371, 2016. 10

13) Ozawa, T., et al.: Crustal deformation associated with the 2016 Kumamoto earthquake and its effect on the magma system of Aso volcano, Earth, Planets and Space, Vol. 68: 186, doi: 10.1186/s40623 -016-0563-5, 2016. 11

14) Satoh, T.: Source, path and site effects of the 2016 Kumamoto earthquake, the foreshocks and aftershocks using the spectral inversion method, JpGU Meeting 2016, MIS34-P71, 2016. 5

15) Satoh, T.: Strong motion generation areas using the empirical green's function method for the 2016 Kumamoto earthquake, Fall meeting of 2016 SSJ, S21-P02, 2016. 10 (in Japanese)

佐藤智美：経験的グリーン関数法に基づく熊本地震の強震動生成域の推 定, 日本地震学会秋季大会, S21-P02, 2016. 10

16) Satoh, T.: Radiation pattern and fmax of the Tottori-ken Seibu earthquake and the aftershocks inferred from Kik-net strong motion records, Journal of Structural and Construction Engineering (Transactions of AIJ), No. 556, pp. 25-34, 2002.6 (in Japanese) 佐藤智美：Kik-net 強震記録に基づく鳥取県西部地震とその余震のラディ エーションパターン及び fmax の評価, 日本建築学会構造系論文集, 第 556 号, pp. 25-34, 2002.6

17) Boore, D. M.: Stochastic simulation of high-frequency ground motions based on seismological models of the radiated spectra, Bull. Seism. Soc. Am., Vol. 73, pp. 1865-1894, 1983. 12

18) Satoh, T. et al.: Statistical spectral characteristics for engineering bedrock waves in which local site effects of surface geology are removed : Based on the ground motion records of small and medium earthquakes observed in the boreholes in Sendai, Journal of 
Structural and Construction Engineering (Transactions of AIJ), No. 462, pp. 79-89, 1994. 8 (in Japanese)

佐藤智美ほか 2 名：表層地盤の影響を取り除いた工学的基盤波の統計的ス ペクトル特性、仙台地域のボアホールで観測された多数の中小地震記録を 用いた解析, 日本建築学会構造系論文集，第 462 号, pp. 79-89, 1994.8

19) Satoh, T.: Short-period spectral level, fmax and attenuation of outerrise, intraslab and interplate earthquakes in the Tohoku district, Journal of Structural and Construction Engineering (Transactions of AIJ), No. 689, pp. 1227-1236, 2013. 7 (in Japanese)

佐藤智美: 東北地方のアウターライズ地震、スラブ内地震、プレート境界 地震の短周期レベルと $\mathrm{fmax}$ 及び距離減衰特性, 日本建築学会構造系論文 集，第 689 号, pp. 1227-1236, 2013. 7

20) 地震調查研究推進本部: 全国地震動予測地図 技術報告書 4. 震源断層を 特定した地震動予測地図平成 21 年 7 月 (オンライン), 入手先 http://jishin.go.jp/main/chousa/09_yosokuchizu/g_shingendanso.pdf, (参照 2017. 7. 20)

21) Fletcher, R.: FORTRAN subroutines for minimization by quasi-Newton methods, Report R7125 AERE, Harwell, England, 1972

22) Tsurugi, M. et al.: Study on a high-cut filter for strong ground motion prediction - Based on the observed records during the 1995 Hyogo-ken Nambu earthquake-, Journal of JAEE, Vol. 6, No. 4, pp. 94-112, 2006. 11 (in Japanese)

鶴来雅人ほか 4 名: 強震動予測のための高域遮断フィルターに関する研究 -1995 年兵庫県南部地震の観測記録に基づく検討一, 日本地震工学会論 文集，第 6 巻，第 4 号, pp. 94-112, 2006.11

23) Dan, K. and Sato, T.: A semi-empirical method for simulating strong ground motions based on variable-slip rupture models for large earthquakes, Bull. Seism. Soc. Am., Vol. 89, pp. 36-53, 1999. 2

24) Uchide, T. et al.: The 2016 Kumamoto-Oita earthquake sequence: aftershock seismicity gap and dynamic triggering in volcanic areas, Earth, Planets and Space, Vol. 68: 180, doi: 10.1186/s40623-0160556-4, 2016. 11

25) Kobayashi, H., Koketsu, K. and Miyake, H. : Rupture processes of the 2016 Kumamoto earthquake sequence: Causes for extreme ground motions, Geophysical Research Letters, Vol. 44, Issue 12, pp. 6002-6010, doi: 10.1002/2017GL073857, 2017. 6

26) Katukura, H. and Hayashi, Y.: Causal FFT treatment applicable to singularity functions, Numerical Methods in Engineering, Vol. 31, No. 1, pp.53-66, 1991. 1

27) Satoh, T., Kawase, H., Iwata, T., Higashi, S., Sato, T. and Huang, H-C.: S-wave velocity structures of sediments estimated from array microtremor records and site responses in the near-fault region of the 1999 Chi-Chi, Taiwan earthquake, Journal of Seismology, Vol. 8, pp. 545-558, 2004. 10

28) Kobayashi, G. and Mamada, Y.: Examination of evaluation method of horizontal strong motions based on strong-to-weak motion (S/W) spectral ratio at the ground surface, Journal of JAEE, Vol. 15, No. 4, pp. 16-39, 2015. 8 (in Japanese)

小林源裕, 儘田豊: 地表観測記録の強震／弱震スペクトル比 $(\mathrm{S} / \mathrm{W}$ スペク トル)に基づく強震時における水平地震動の評価法の検討, 日本地震工学 会論文集，第 15 巻，第 4 号, pp. 16-39, 2015. 8

29) Satoh, T.: Source modeling of the 2011 off the Pacific coast of Tohoku earthquake using empirical Green's function method, From the viewpoint of the short period spectral level of interplate earthquakes, Journal of Structural and Construction Engineering (Transactions of AIJ), No. 675, pp. 695-704, 2012. 5 (in Japanese)

佐藤智美：経験的グリーン関数法に基づく 2011 年東北地方太平洋沖地震 の震源モデル，プレート境界地震の短周期レベルに着目して, 日本建築学 会構造系論文集，第 675 号, pp. 695-704, 2012.5

30) Miyake, H. et al.: Strong ground motion simulation and source modeling of the Kagoshima-ken Hokuseibu earthquakes of March 26 (M $\left.\mathrm{M}_{\mathrm{JMA}} 6.5\right)$ and May 13 ( $\left.\mathrm{M}_{\mathrm{JMA}} 6.3\right)$, 1997, using empirical Green's function method, Zisin, Vol. 51, No. 4, pp. 431-442, 1999. 3 (in
Japanese)

三宅弘恵ほか 2 名：経験的グリーン関数法を用いた 1997 年 3 月 26 日 （MJMA6.5）及び5月 13 日（MJMA6.3）鹿児島県北西部地震の強震動シミュ レーションと震源モデル，地震 第 2 輯, 第 51 巻, 第 4 号, pp. 431-442, 1999. 3

31) Miyake, H. et al.: Source characterization for broadband ground-motion simulation: Kinematic heterogeneous source model and strong motion generation area, Bull. Seism. Soc. Am., Vol. 93, No. 6, pp. 2531-2545, 2003. 12

32) Nakata, T. and Imaizumi, T.: Digital active fault map of Japan, University of Tokyo press, 2002. 2 (in Japanese)

中田高, 今泉俊文：活断層詳細デジタルマップ, 東京大学出版会, 2002.2

33) Geographical Survey Institute: Digital map 250m grid (elevation), Japan, CD-ROM version, 1997 (in Japanese)

国土地理院：数值地図 $250 \mathrm{~m}$ メッシュ(標高), 全国, CD-ROM 版, 1997

34) Eshelby, J. D.: The determination of the elastic field of an ellipsoidal inclusion, and related problems, Proceedings of the Royal Society of London, Series A, Mathematical and Physical Sciences, Vol. 241, pp. 376-396, 1957

35) Uchiyama, Y. and Yamamoto, Y.: Short-period spectral level and path characteristics of the 2016 Kumamoto earthquake using spectral inversion method, Journal of JAEE, Vol. 16, No. 10, pp. 146-150, 2016. 11 (in Japanese)

内山泰生, 山本優：スペクトルインバージョン解析に基づく 2016 年熊本 地震の震源 ・伝播経路特性の評価, 日本地震工学会論文集, 第 16 巻, 第 10 号, pp.146-150, 2016. 11

36) Dan, K. et al.: Short-period source spectra inferred from variable-slip rupture models and modeling of earthquake faults for strong motion prediction by semi-empirical method, Journal of Structural and Construction Engineering (Transactions of AIJ), No. 545, pp. 51-62, 2001. 7 (in Japanese)

壇一男ほか 3 名：断層の非一様すべり破壊モデルから算定される短周期レ ベルと半経験的波形合成法による強震動予測のための震源断層のモデル 化, 日本建築学会構造系論文集, 第 545 号, pp. 51-62, 2001. 7

37) Satoh, T.: Scaling law of short-period source spectra for crustal earthquakes in Japan considering style of faulting of dip-slip and strike-slip, Journal of Structural and Construction Engineering (Transactions of AIJ), No. 651, pp. 923-932, 2010. 5 (in Japanese) 佐藤智美：逆断層と横ずれ断層の違いを考慮した日本の地殼内地震の短 周期レベルのスケーリング則, 日本建築学会構造系論文集, 第 651 号, pp. 923-932, 2010. 5

38) Satoh, T. and Okazaki, A.: Relation between stress drops and depths of strong motion generation areas based on previous broadband source models for crustal earthquakes in Japan earthquakes, Tsunamis and Nuclear Risks, pp. 77-85, Springer, 2016. 1

39) Somerville, P. G. et al.: Characterizing crustal earthquake slip models for the prediction of strong ground motion, Seismol. Res. Lett., Vol. 70, pp. 59-80, 1999. 1

40) Irikura, K. and Miyake, H.: Prediction of strong ground motions for scenario earthquake. Journal of Geography, Vol. 110, pp. 849-875, 2001 (in Japanese)

入倉孝次郎，三宅弘恵：シナリ才地震の強震動予測，地学雑誌，Vol. 110, pp. 849-875, 2001

41) Nozu, A.: A simple scheme to introduce near-field and intermediate-field terms in stochastic Green's functions, The 12th Japan Earthquake Engineering Symposium, pp. 190-193, 2006. 11 (in Japanese)

野津厚：統計的グリーン関数に近地項と中間項を導入するための簡便な 方法, 第 12 回日本地震工学シンポジウム, pp. 190-193, 2006. 11

42) Wessel, P. and Smith, W.H.F.: New, improved version of Generic Mapping Tools released, EOS, AGU, 1998 


\title{
BROADBAND SOURCE CHARACTERISTICS OF THE 2016 KUMAMOTO \\ EARTHQUAKE ESTIMATED FROM STRONG MOTION RECORDS
}

\author{
Toshimi SATOH* \\ ${ }^{*}$ Institute of Technology, Shimizu Corporation, Chief Researcher, Dr.Eng.
}

We estimate the broadband source model of the 2016 Kumamoto earthquake (M $\mathrm{M}_{\mathrm{J}}$ 7.3, Mw7.1) based on the empirical Green's function method in order to improve strong motion predictions of crustal earthquakes. Firstly we estimate fmax of 37 earthquakes with $\mathrm{M}_{\mathrm{J}} 4.0$ to 7.3 occurring in the source region of the main shock using source spectra estimated by the spectral inversion analysis in our previous paper. The estimated fmax of the main shock is $4.4 \mathrm{~Hz}$, which is smaller than $6 \mathrm{~Hz}$ for the strike-slip earthquakes with almost the same magnitude. The fmax tends to increase in accordance with the magnitude decreases. The differences of the fmax between the main shock and Mw5-class two element earthquakes are corrected. The nonlinear amplification factors of strong motions during the main shock are also corrected using horizontal-to-vertical spectral ratios between strong motions and weak motions at K-NET stations. After these corrections we estimate the broadband source model of the main shock using K-NET and KiK-net (borehole) strong motion records at 18 stations.

We study three cases of outer faults as regions searching strong motion generation areas (SMGAs). In the first case (A-model), two northwest-dipping faults around the Futagawa fault and the Hinagu fault are assumed. In the other cases (Y-model and K-model) only the northeastern part of the Futagawa fault near Mt. Aso is changed to be a southeast-dipping fault based on crustal deformation data and some newly developed source models. Since few aftershocks were occurred there, we assume Y-model and K-model with different strike and dip angles. After estimating the broadband source model for A-model by the forward modeling, the broadband source models for Y-model and K-model are estimated by the grid search method using evaluation functions for envelopes of acceleration and waveforms of velocity filtered in the period range of 0.1 to $5 \mathrm{~s}$.

The Y-model is the best and the A-model is the second best although the difference of the evaluation-function-value of both models is small. The plane positions of the SMGAs on the fault near Mt. Aso are the almost the same between Y-model and A-model and is in the so-called Aso gap where few aftershocks were occurred. The SMGAs for both models extend to the inside of northwestern region of the Aso caldera. For the Y-model the short-period spectral level is almost the average for crustal earthquakes by Dan et al. (2001) and the total area of SMGAs are 1.16 times of the average for the total area of asperities for crustal earthquakes by Somerville et al. (1999). The $11.5 \mathrm{MPa}$ of stress drop of five SMGAs is almost the average for crustal earthquakes. The source parameters of A-model are also almost same to previous relations for crustal earthquakes. The results on scaling relations are consistent with Irikura et al. (2017) in general but the existence of SMGAs inside Aso caldera is different from Irikura et al. (2017). The rupture velocity of 2.8 $\mathrm{km} / \mathrm{s}$ for SMGAs on the Futagawa fault is faster than $2.4 \mathrm{~km} / \mathrm{s}$ for the SMGA on the Hinagu fault. The positions of SMGAs located in the northeast side on the northwest-dipping Futagawa fault agree better to high peak moment rate areas than large slip areas estimated by Yoshida et al. (2017). This result suggests that short-period ground motions generate slightly deeper areas than long-period ground motions. It is qualitatively found that strong motions with large velocity pulses observed at KMMH16 (Mashiki) in borehole are generated by the SMGA located in shallow depth just beneath KMMH16. 